\title{
Implementasi Konsep Ramah Lingkungan Pada Fasilitas Pendidikan Sekolah Dasar Di Jakarta
}

\author{
Sultan Rasyid ${ }^{1}$, Muzaki ${ }^{1}$ \\ ${ }^{1}$ Program Studi PKLH Pascasarjana Universitas Negeri Makassar \\ Email : sultanrasyidunm@gmail.com
}

(C) 2019 - UEJ Program Studi Pendidikan Kependudukan dan Lingkungan Hidup Universitas Negeri Makassar Ini adalah artikel dengan akses terbuka dibawah Licensi CC BY-NC-4.0

(https://creativecommons.org/licenses/by-nc/4.0/ )

\begin{abstract}
Abstrak. Sekolah sebagai institusi pendidikan merupakan salah satu target utama yang dilibatkan dalam pengelolaan lingkungan hidup melalui implementasi dalam menerapkan konsep ramah lingkungan pada fasilitas pendidikan. Implementasi konsep ramah lingkungan pada dasarnya telah dikembangkan oleh berbagai sekolah yang lebih populer dengan istilah green school. Penelitian ini merupakan penelitian diskriptif kuantitatif dengan responden yaitu 30 orang kepala SD negeri dan 30 orang kepala SD swasta di Jakarta. Teknik pengumpulan data meliputi kuesioner, pengamatan langsung dan dokumentasi ke sekolah yang bersangkutan. Kesimpulan yang dapat ditarik dari penelitian ini adalah 1). Tingkat keberhasilan implementasi konsep ramah lingkungan pada fasilitas pendidikan SD di Jakarta termasuk dalam kategori tinggi, baik untuk ketersediaan maupun peningkatan kualitas. 2) Tidak ada perbedaan tingkat keberhasilan implementasi konsep ramah lingkungan pada fasilitas pendidikan Sekolah Dasar di Jakarta antara SD negeri dan SD swasta.
\end{abstract}

Keywords: Implementasi, Ramah Lingkungan, Pendidikan.

\section{PENDAHULUAN}

Agenda lingkungan hidup kini sudah menjadi agenda internasional di segala bidang, baik politik, perdagangan dan industri. Agenda ini muncul dan semakin menguat karena kesadaran lingkungan kini semakin merata justru karena kekhawatiran yang semakin besar dengan terancamnya kualitas bumi kita sebagai satu-satunya tempat hidup di alam semesta. Isu lingkungan merupakan masalah yang sudah menjadi masalah global (mendunia). Memasuki abad ke-21, dunia sebenarnya sedang memasuki zaman lingkungan, tepatnya era restorasi lingkungan yang didasari oleh cinta pada bumi dan segenap kehidupan di dalamnya. Gencarnya pembangunan berbasis industri disegala sektor telah menggantikan lahan yang seharusnya digunakan untuk kepentingan dan kelestarian lingkungan (Ramdhani, 2017). Kondisi tersebut juga telah merambah berbagai wilayah di Indonesia, sehingga berpotensi merusak lingkungan. Oleh karena itu, Indonesia masih memiliki sejumlah persoalan lingkungan yang membutuhkan penyelesaian. Persoalan ini menjadi sangat krusial karena menyangkut kualitas kehidupan di masa datang.

Persoalan terkait kerusakan lingkungan tersebut diantaranya adalah sampah. Hal ini tak pelak menimbulkan sejumlah persoalan lanjutan, diantaranya adalah produksi sampah dan pembuangannya. Menurut data Kementerian Lingkungan Hidup dan Kehutanan, Indonesia, dengan jumlah penduduk terbesar ke-4 di dunia setelah India, China dan US (data 2019), memproduksi sampah hingga 65 juta ton pada 2016. Jumlah ini naik 1 juta ton dari tahun sebelumnya. Persoalan lingkungan lainnya adalah banjir. Selain tingginya curah hujan, banjir merupakan dampak yang dihasilkan dari berbagai permasalahan lingkungan lain seperti gunungan sampah, rusaknya hutan dan berubahnya fungsi sungai. Persoalan lainnya adalah pencemaran udara. Indonesia merupakan salah satu negara dengan jumlah pengguna sepeda motor terbanyak di dunia. Data Korlantas Polri menyebutkan jumlah 
kendaraan yang terdaftar per 3 Januari 2017 mencapai 102.328 .629 kendaraan. Kondisi ini menimbulkan munculnya masalah pencemaran udara (Koran Sindo Online, 2018).

Dengan meningkatnya masalah lingkungan berupa pencemaran lingkungan dan berkurangnya sumberdaya alam diperlukan pemahaman akan upaya pelestarian lingkungan. UU Nomor 32 tahun 2009 tentang Perlindungan dan Pengelolaan Lingkungan Hidup pada point ke empat dari pasal 65 menyebutkan bahwa "setiap orang berhak dan berperan dalam pengelolaan lingkungan". Ini berarti bahwa siapapun dia baik pemerintah maupun masyarakat mempunyai kewajiban untuk ikut dalam upaya perlindungan dan pengelolaan lingkungan (Putri et al., 2018).

Sekolah sebagai Institusi pendidikan dan juga merupakan wadah pendidikan bagi manusia merupakan target utama untuk dilibatkan dalam upaya pengelolaan lingkungan hidup lewat implementasi dalam menerapkan konsep ramah lingkungan pada fasilitas pendidikan. Implementasi konsep ramah lingkungan pada dasarnya telah dikembangkan berbagai sekolah yang populer dengan sebutan green school. Green School merupakan program pemerintah yang diharapkan mampu memiliki pemahaman, kesadaran, dan mengintegrasikan nilai-nilai lingkungan hidup pada seluruh warga sekolah agar membentuk perilaku dan pola pengelolaan sekolah yang ramah lingkungan untuk menjaga kelestarian lingkungan. Program Green School menjadi ikon penting dalam rangka antisipasi global warming karena dengan membangkitkan rasa tanggungjawab, peduli, dan percaya diri kepada peserta didik SD, SMP dan SMA untuk ikut serta dalam upaya meminimalisir pemanasan global (Kristiawan et al., 2019).

Konsep "Green" yang dimaksud dapat diinterpretasikan sebagai sustainable (berkelanjutan), earthfriendly (ramah lingkungan), dan high performance building (bangunan dengan perfoma sangat baik). Desain ini memaksimalkan penanaman pohon dan rerumputan untuk menciptakan proporsi yang lebih seimbang, dan juga agar suhu dalam ruangan tetap serasa sejuk. Green School menggunakan metode pembelajaran yang lebih menyenangkan, yakni dengan mengajak peserta didiknya untuk masuk langsung kedalam kehidupan nyata singkatnya dapat dikatakan bahwa metode yang digunakan adalah belajar sambil bermain. Selain Green School terdapat pula konsep pembelajaran yang berbeda yaitu International School. Sebuah bangunan sekolah atau fasilitas yang menciptakan sehat lingkungan yang kondusif untuk belajar sambil menyimpan energi, sumber daya, dan uang. Green school "Sekolah Hijau" yaitu sekolah yang memiliki komitmen dan secara sistematis mengembangkan programprogram untuk menginternalisasikan nilai-nilai lingkungan ke dalam seluruh aktifitas sekolah (Priyadi dkk, 2018:2).

Implementasi konsep ramah lingkungan oleh pemerintah diwujudkan dengan adanya program sekolah Adiwiyata. Program Adiwiyata akan menciptakan warga sekolah khususnya siswa yang mau peduli, bertanggung jawab dalam upaya perlindungan dan pengelolaan lingkungan hidup melalui tata kelola sekolah yang baik. Program Adiwiyata yang dicanangkan oleh pemerintah ternyata belum banyak diketahui oleh masyarakat (Jusman et al., 2018). Program Adiwiyata tidak memiliki intensif materi dan hanya diperuntukkan bagi sekolah-sekolah yang bersedia secara sukarela. Program Adiwiyata dalam pelaksanaannya masih banyak mengalami kendala. Oleh karena itu pada tanggal 1 Februari 2010 dilaksanakan pendandatanganan kesepakatan bersama (MOU-Memorandum of Understanding) antara Kementerian Lingkungan Hidup dengan Kementerian Pendidikan Nasional. Tujuan utama dari kesepakatan ini yaitu agar Pendidikan Lingkungan Hidup (PLH) dapat terintegrasi dalam kurikulum pendidikan nasional sehingga dapat mewujudkan perubahan perilaku peserta didik menjadi ramah lingkungan (http://www.menlh.go.id/penandatanganan/). Namun saat ini penerapan sekolah ramah lingkungan di Indonesia belum banyak diketahui oleh masyarakat.

Implementasi konsep ramah lingkungan dapat menjadi solusi untuk menyediakan fasilitas pendidikan yang aman bagi siswa (Istiadi, 2018). Salah satu wilayah yang telah mengimplementasikan adalah SD di Jakarta. Hal ini tercermin dari berbagai fasilitas pendidikan yang ramah lingkungan seperti sekolah yang bersih dan hijau, adanya pengelolaan sampah secara terpadu, dan lain-lain. Akan tetapi, berdasarkan studi pendahuluan, masih ditemui sejumlah kendala dalam mengimplementasikan konsep ramah lingkungan, misalnya kurangnya dukungan fasilitas serta kurangnya disiplin anak dalam mengikuti program ramah lingkungan di sekolah tersebut. Berdasarkan latar belakang tersebut, maka peneliti tertarik untuk mengetahui lebih dalam mengenai "Implementasi Konsep Ramah Lingkungan pada Fasilitas Pendidikan Sekolah Dasar di Jakarta”. 


\section{Sultan Rasyid, Implementasi Konsep Ramah Lingkungan}

Adapun tujuan penelitiannya adalah (1) mengetahui keberhasilan implementasi konsep ramah lingkungan pada fasilitas pendidikan SD di Jakarta dan (2) mengetahui perbedaan keberhasilan implementasi konsep ramah lingkungan pada fasilitas pendidikan SD di Jakarta antara SD negeri dan SD swasta.

\section{METODE}

Penelitian ini merupakan penelitian diskriptif kuantitatif dengan fokus pada kajian objek alamiah yang lebih menekankan makna daripada generalisasi (Sugiyono, 2015: 1). Populasi dalam penelitian ini adalah 30 orang kepala SD negeri di Jakarta dan 30 orang kepala SD swasta di Jakarta.

Teknik pengumpulan data meliputi kuesioner, pengamatan dan dokumentasi. Instrumen penelitian adalah peneliti sendiri dengan bantuan pedoman angket, observasi, dan dokumentasi. Teknik analisis data yang digunakan dalam penelitian ini adalah metode analisis deskriptif kuantitatif dimana kuesioner terbagi atas 2 indikator yaitu: 1) Ketersediaan sarana prasarana pedukung yang ramah lingkungan; dan 2) Peningkatan kualitas pengelolaan dan pemanfaatan sarana dan prasarana yang ramah lingkungan dengan uraian sub indikator dapat dilihat pada table 1.

Analisis terhadap variabel penelitian menggunakan analisis deskriptif yang berdasarkan pada rata-rata total pada setiap item pertanyaan. Sebelum dilakukan analisis lebih lanjut terlebih dahulu dilakukan pengkategorian untuk menentukan penilaian pada masing-masing variabel penelitian. Pengkategorian ini didasarkan pada penilaian terendah yaitu 1 (sangat tidak setuju), dan skor tertinggi adalah 4 (sangat setuju) (Sugiyono, 2015).

\section{HASIL PENELITIAN DAN PEMBAHASAN}

Tingkat keberhasilan implementasi konsep ramah lingkungan pada fasilitas pendidikan SD di Jakarta dapat dilihat dari dua indikator yaitu ketersediaan sarana prasarana pendukung serta peningkatan kualitas pengelolaan dan pemanfaatan sarana dan prasarana.

\section{Deskripsi Responden Penelitian}

Berdasarkan hasil penelitian yang dilakukan pada guru SD di Jakarta, maka dapat dideskripsikan usia responden penelitian dalam tabel sebagai berikut:

Tabel 1. Usia responden penelitan

\begin{tabular}{|c|c|c|c|c|}
\hline \multirow{2}{*}{ Usia } & \multicolumn{2}{|c|}{ Negeri } & \multicolumn{2}{c|}{ Swasta } \\
\cline { 2 - 5 } & Frek & $\begin{array}{c}\text { Prosen } \\
(\%)\end{array}$ & Frek & $\begin{array}{c}\text { Prosen } \\
(\%)\end{array}$ \\
\hline $\begin{array}{c}30-40 \\
\text { tahun }\end{array}$ & 13 & 43,3 & 26 & 86,7 \\
\hline $\begin{array}{c}41-50 \\
\text { tahun }\end{array}$ & 13 & 43,3 & 4 & 13,3 \\
\hline $\begin{array}{c}51-60 \\
\text { tahun }\end{array}$ & 4 & 13,3 & 0 & 0,0 \\
\hline Jumlah & 30 & 100,0 & 30 & 100,0 \\
\hline
\end{tabular}

Berdasarkan tabel tersebut diatas dapat diketahui bahwa sebagian besar guru SD Negeri berusia 30 - 40 tahun atau 41 - 50 tahun (masing-masing 43,3\%) dan terakhir 51 - 60 tahun $(13,3 \%$ ). Sedangkan guru swasta sebagian besar guru berusia $30-40$ tahun $(86,7 \%)$ dan terakhir $41-60$ tahun $(13,3 \%)$. 
UNM Environmental Journals, Vol. 2 No. 2 April hal. $44-51$

\section{Deskripsi Responden Penelitian berdasarkan indikator ketersediaan sarana prasarana pendukung}

Tingkat keberhasilan implementasi konsep ramah lingkungan pada fasilitas pendidikan SD di Jakarta berdasarkan indikator ketersediaan sarana prasarana pendukung dapat dilihat tabel berikut ini :.

Tabel 2. Tingkat ketersediaan sarana prasarana pendukung yang ramah lingkungan pada fasilitas pendidikan SD di Jakarta

\begin{tabular}{|c|c|c|}
\hline $\begin{array}{c}\text { Ketersediaan } \\
\text { Sarana Prasarana }\end{array}$ & Frek & $\begin{array}{c}\text { Prosen } \\
(\%)\end{array}$ \\
\hline Tinggi & 58 & 96,7 \\
\hline Sedang & 2 & 3,3 \\
\hline Rendah & 0 & 0,0 \\
\hline Jumlah & 60 & 100,0 \\
\hline
\end{tabular}

Tingkat ketersediaan sarana prasarana pendukung yang ramah lingkungan pada fasilitas pendidikan SD di Jakarta, sebagian besar termasuk dalam kategori tinggi $(96,7 \%)$ kemudian diikuti kategori sedang $(3,3 \%)$, dan kategori rendah tidak ada. Hal ini menunjukkan bahwa ketersediaan sarana prasarana pendukung yang ramah lingkungan pada fasilitas pendidikan SD di Jakarta termasuk dalam kategori tinggi.

Deskripsi Responden Penelitian berdasarkan indikator peningkatan kualitas pengelolaan dan pemanfaatan sarana dan prasarana

Tingkat keberhasilan implementasi konsep ramah lingkungan pada fasilitas pendidikan SD di Jakarta berdasarkan indikator peningkatan kualitas pengelolaan dan pemanfaatan sarana dan prasarana dapat dilihat tabel berikut ini :.

Tabel 3. Tingkat peningkatan kualitas pengelolaan dan pemanfaatansarana dan prasarana pada fasilitas pendidikan SD di Jakarta

\begin{tabular}{|c|c|c|}
\hline $\begin{array}{c}\text { Ketersediaan } \\
\text { Pengelolaan dan } \\
\text { Pemanfaatan }\end{array}$ & Frek & Prosen (\%) \\
\hline Tinggi & 48 & 80 \\
\hline Sedang & 12 & 20 \\
\hline Rendah & 0 & 0 \\
\hline Jumlah & 60 & 100 \\
\hline
\end{tabular}

Tingkat peningkatan kualitas pengelolaan dan pemanfaatan sarana dan prasarana pada fasilitas pendidikan SD di Jakarta, sebagian besar termasuk dalam kategori tinggi $(80 \%)$ kemudian diikuti kategori sedang (20\%), dan kategori rendah tidak ada. Hal ini menunjukkan bahwa peningkatan kualitas pengelolaan dan pemanfaatan sarana dan prasarana pada fasilitas pendidikan SD di Jakarta termasuk dalam kategori tinggi.

Tingkat keberhasilan implementasi konsep ramah lingkungan pada fasilitas pendidikan SD di Jakarta secara keseluruhan dapat dilihat dalam tabel berikut ini: 
Tabel 4. Tingkat Keberhasilan Implementasi Konsep Ramah Lingkungan pada fasilitas pendidikan SD di Jakarta

\begin{tabular}{|c|c|c|}
\hline $\begin{array}{c}\text { Tingkat } \\
\text { Keberhasilan }\end{array}$ & Frek & Prosen $(\%)$ \\
\hline Tinggi & 48 & 80 \\
\hline Sedang & 12 & 20 \\
\hline Rendah & 0 & 0 \\
\hline Jumlah & 60 & 100 \\
\hline
\end{tabular}

Tingkat peningkatan kualitas pengelolaan dan pemanfaatan sarana dan prasarana pada fasilitas pendidikan SD di Jakarta, sebagian besar termasuk dalam kategori tinggi $(80 \%)$ kemudian diikuti kategori sedang (20\%), dan kategori rendah tidak ada. Sedangkan tingkat keberhasilan implementasi konsep ramah lingkungan pada fasilitas pendidikan SD di Jakarta berdasarkan SD Negeri dan SD Swasta dapat dilihat dalam tabel berikut ini:

Tabel 5. tingkat keberhasilan implementasi konsep ramah lingkungan pada fasilitas pendidikan SD di Jakarta

\begin{tabular}{|c|c|c|c|c|}
\hline \multirow{2}{*}{ Tingkat } & \multicolumn{2}{|c|}{ Negeri } & \multicolumn{2}{c|}{ Swasta } \\
\cline { 2 - 5 } & Frek & $\begin{array}{c}\text { Prosen } \\
(\%)\end{array}$ & Frek & $\begin{array}{c}\text { Prosen } \\
(\%)\end{array}$ \\
\hline Tinggi & 26 & 86,7 & 22 & 73,3 \\
\hline Sedang & 4 & 13,3 & 8 & 26,7 \\
\hline Rendah & 0 & 0,0 & 0 & 0,0 \\
\hline Jumlah & 30 & 100,0 & 30 & 100,0 \\
\hline
\end{tabular}

Berdasarkan tabel tersebut diatas dapat diketahui bahwa tingkat keberhasilan implementasi konsep ramah lingkungan pada fasilitas pendidikan SD Negeri di Jakarta, sebagian besar termasuk dalam kategori tinggi $(86,7 \%)$ kemudian diikuti kategori sedang $(13,3 \%)$, dan kategori rendah tidak ada. Tingkat keberhasilan implementasi konsep ramah lingkungan pada fasilitas pendidikan SD Swasta di Jakarta, sebagian besar termasuk dalam kategori tinggi $(73,3 \%)$ kemudian diikuti kategori sedang $(26,7 \%)$, dan kategori rendah tidak ada.

\section{Perbedaan Tingkat Keberhasilan Implementasi Konsep Ramah Lingkungan}

Perbedaan tingkat keberhasilan implementasi konsep ramah lingkungan pada fasilitas pendidikan SD di Jakarta dapat dilihat dari dua indikator yaitu ketersediaan sarana prasarana pendukung serta peningkatan kualitas pengelolaan dan pemanfaatan sarana dan prasarana.

\section{Ketersediaan sarana prasarana pendukung}

Perbedaan tingkat keberhasilan implementasi konsep ramah lingkungan pada fasilitas pendidikan SD di Jakarta berdasarkan indikator ketersediaan sarana prasarana pendukung dapat dilihat tabel berikut ini :

Tabel 6. Perbedaan Ketersediaan Sarana Prasarana Pendukung yang Ramah Lingkungan pada Fasilitas Pendidikan SD di Jakarta. 
UNM Environmental Journals, Vol. 2 No. 2 April hal. $44-51$

\begin{tabular}{|c|c|c|c|}
\hline $\begin{array}{c}\text { Ketersediaan } \\
\text { sarana prasarana }\end{array}$ & Frek & $\begin{array}{c}\text { Prosen } \\
(\%)\end{array}$ & $\mathrm{p}$ \\
\hline SD Negeri & 2,99 & $-1,983$ & 0,047 \\
\hline SD Swasta & 3,04 & $-1,04$ \\
\hline
\end{tabular}

Tingkat keberhasilan implementasi konsep ramah lingkungan pada fasilitas pendidikan SD dengan indikator ketersediaan sarana prasarana pendukung di Jakarta untuk SD Negeri mempunyai nilai rata-rata sebesar 2,99 sedangkan SD Swasta sebesar 3,04 dengan nilai $\mathrm{p}=0,047<0,05$, hal ini berarti ada perbedaan secara signifikan.

\section{Ketersediaan sarana prasarana pendukung}

Perbedaan tingkat keberhasilan implementasi konsep ramah lingkungan pada fasilitas pendidikan SD di Jakarta berdasarkan indikator peningkatan kualitas pengelolaan dan pemanfaatan sarana dan prasarana dapat dilihat tabel berikut ini:

Tabel 7. Perbedaan Peningkatan Kualitas Pengelolaan dan Pemanfaatan Sarana dan Prasarana pada Fasilitas Pendidikan SD

di Jakarta.

\begin{tabular}{|c|c|c|c|}
\hline $\begin{array}{c}\text { Ketersediaan } \\
\text { sarana prasarana }\end{array}$ & Frek & $\begin{array}{c}\text { Prosen } \\
(\%)\end{array}$ & $\mathrm{p}$ \\
\cline { 1 - 2 } SD Negeri & 3,02 & $-1,106$ & 0,269 \\
\hline SD Swasta & 3,01 & -106 \\
\hline
\end{tabular}

Tingkat keberhasilan implementasi konsep ramah lingkungan pada fasilitas pendidikan SD dengan indikator peningkatan kualitas pengelolaan dan pemanfaatan sarana dan prasarana di Jakarta untuk SD Negeri mempunyai nilai rata-rata sebesar 3,02 sedangkan SD Swasta sebesar 3,01 dengan nilai $p=0,269>0,05$, hal ini berarti tidak ada perbedaan secara signifikan.

\section{Perbedaan Tingkat Keberhasilan Implementasi Konsep Ramah Lingkungan secara Keseluruhan}

Adapun perbedaan tingkat keberhasilan implementasi konsep ramah lingkungan pada fasilitas pendidikan SD di Jakarta secara keseluruhan dapat dilihat dalam tabel berikut ini.

Tabel 8. Perbedaan tingkat keberhasilan implementasi konsep ramah lingkungan pada fasilitas pendidikan SD di Jakarta

\begin{tabular}{|c|c|c|c|}
\hline $\begin{array}{c}\text { Ketersediaan } \\
\text { sarana prasarana }\end{array}$ & Frek & $\begin{array}{c}\text { Prosen } \\
(\%)\end{array}$ & $\mathrm{p}$ \\
\hline SD Negeri & 3,00 & \multirow{2}{*}{$-1,106$} & 0,269 \\
\hline SD Swasta & 3,03 & \\
\hline
\end{tabular}

Tingkat keberhasilan implementasi konsep ramah lingkungan pada fasilitas pendidikan SD di Jakarta untuk SD Negeri mempunyai nilai rata-rata sebesar 3,00sedangkan SD Swasta sebesar 3,03 dengan nilai $\mathrm{p}=0,269>0,05$, hal ini berarti tidak ada perbedaan secara signifikan. 


\section{Sultan Rasyid, Implementasi Konsep Ramah Lingkungan}

\section{Pembahasan}

Implementasi konsep ramah lingkungan pada dasarnya telah dikembangkan berbagai sekolah yang populer dengan sebutan green school. Green School merupakan program pemerintah yang diharapkan mampu memiliki pemahaman, kesadaran, dan mengintegrasikan nilai-nilai lingkungan hidup pada seluruh warga sekolah agar membentuk perilaku dan pola pengelolaan sekolah yang ramah lingkungan untuk menjaga kelestarian lingkungan. Implementasi konsep ramah lingkungan oleh pemerintah diwujudkan dengan adanya program sekolah Adiwiyata. Program Adiwiyata akan menciptakan warga sekolah khususnya siswa yang mau peduli, bertanggung jawab dalam upaya perlindungan dan pengelolaan lingkungan hidup melalui tata kelola sekolah yang baik. Program Adiwiyata yang dicanangkan oleh pemerintah ternyata belum banyak diketahui oleh masyarakat. Program Adiwiyata tidak memiliki intensif materi dan hanya diperuntukkan bagi sekolah-sekolah yang bersedia secara sukarela.

Implementasi konsep ramah lingkungan dapat menjadi solusi untuk menyediakan fasilitas pendidikan yang aman bagi siswa. Salah satu wilayah yang telah mengimplementasikan adalah SD di Jakarta. Tingkat keberhasilan implementasi konsep ramah lingkungan pada fasilitas pendidikan SD Negeri di Jakarta, sebagian besar termasuk dalam kategori tinggi $(86.7 \%)$ kemudian diikuti kategori sedang $(13,3 \%)$, dan kategori rendah tidak ada. Tingkat keberhasilan implementasi konsep ramah lingkungan pada fasilitas pendidikan SD Swasta di Jakarta, sebagian besar termasuk dalam kategori tinggi $(73,3 \%)$ kemudian diikuti kategori sedang $(26,7 \%)$, dan kategori rendah tidak ada. Berdasarkan analisis menggunakan Mann Whitney menunjukkan tidak ada perbedaan tingkat keberhasilan implementasi konsep ramah lingkungan pada fasilitas pendidikan baik SD Negeri maupun SD Swasta. Namun demikian tingkat keberhasilan implementasi konsep ramah lingkungan pada fasilitas pendidikan dengan indikator ketersediaan SD Swasta lebih baik dibandingkan dengan SD Negeri, sehingga ada perbedaan yang berarti. Sedangkan tingkat keberhasilan implementasi konsep ramah lingkungan pada fasilitas pendidikan dengan indikator pemeliharaan antara SD Negeri dan SD Swasta tidak ada perbedaan yang berarti.

\section{KESIMPULAN}

Kesimpulan yang dapat ditarik dari penelitian ini adalah sebagai berikut:

a) Tingkat keberhasilan implementasi konsep ramah lingkungan pada fasilitas pendidikan SD di Jakarta termasuk dalam kategori tinggi, baik untuk SD Negeri maupun SD Swasta.

b) Tidak ada perbedaan tingkat keberhasilan implementasi konsep ramah lingkungan pada fasilitas pendidikan Sekolah Dasar di Jakarta antara SD negeri dan SD swasta.

Berdasarkan hasil penelitian yang diperoleh maka disarankan beberapa hal sebagai berikut:

a) Bagi Kepala Sekolah Dasar Negeri maupun Swasta di Jakarta supaya tetap mempertahankan implementasi konsep ramah lingkungan pada fasilitas pendidikan.

b) Penelitian lebih lanjut disarankan agar penelitian ini dikembangkan dengan menggunakan analisis yang lebih mendalam seperti wawancara (in-depth interview) maupun forum diskusi 
UNM Environmental Journals, Vol. 2 No. 2 April hal. $44-51$

\section{Referensi}

Istiadi, Y., 2018. Pendidikan lingkungan hidup terlupakan dalam kurikulum.

Jusman, J., Ardi, M., Rauf, B., 2018. Gambaran Pelaksanaan Program Adiwiyata di SD Pertiwi Kota Makassar. UNM Environ. J. 1, 59-66.

Kristiawan, M., Maryanti, N., Fitria, H., 2019. Membangun Karakter Peserta Didik Melalui Green School Di Smk Negeri 2 Muara Enim. JMKSP J. Manaj. Kepemimp. Dan Supervisi Pendidik.4.

Putri, R.I., Mahmudi, I., Pujiantara, M., Priyadi, A., Taufik, T., Purnomo, M.H., 2018. Modified Firefly Algorithm for Improved Maximum Power Extraction on Wind Energy Conversion System. Int. J. Renew. Energy Res. IJRER 8, 1208-1216.

Ramdhani, R.B., 2017. Penerapan Penilaian Portofolio Untuk Meningkatkan Karakter Mandiri Peserta Didik Dalam Pembelajaran IPS:(Penelitian Tindakan Kelas di Kelas VIII-D SMP Negeri 3 Sukabumi) (PhD Thesis). Universitas Pendidikan Indonesia.

Sugiyono, P., 2015. Metode penelitian kombinasi (mixed methods). Bdg. Alf. 